Ann. Biol. anim. Bioch. Biophy's., I975, 15 (2), 389-406.

\title{
CHARACTERISTICS OF PROSTAGLANDINS
}

\author{
A. L. WALPOLE \\ Biological Research Department, \\ Imperial Chemical Industries Limited \\ (Pharmaceuticals Division), Mereside \\ Alderley Park, Macclesfield, Cheshire (England)
}

\section{SUMMARY}

The natural prostaglandins (PGs) are all unsaturated hydroxy acids of 20 carbon atoms based on a 5 -membered ring with 2 adjacent side-chains. There are four main series, designated $\mathrm{E}, \mathrm{F}, \mathrm{A}$ and $\mathrm{B}$, denoting differences in the ring. They occur widely in mammalian tissues but in very low concentrations except in the seminal fluid of certain species, including man. In human semen, the richest source, at least I 5 PGs have now been identified, in a total concentration of ca. $300 \mu \mathrm{g} / \mathrm{ml}$. The PGs are formed in many tissues, often in response to stimulation, by biosynthesis from unsaturated fatty acids, e.g. arachidonic. After release into the circulation the PGFs are very rapidly metabolised, mainly in the lung and liver, to inactive urinary excretion products. PGAs are rather less rapidly inactivated.

The PGs have a remarkably wide range of pharmacological activities, in respect of which they are often extremely potent. Members of the different series exhibit different specificities of action, and pharmacological responses are often species-dependent. PGEs usually lower blood pressure, stimulate gastro-intestinal and uterine smooth muscle and relax respiratory smooth muscle. PGFs have pressor effects in some species, and in some cause broncho-constriction. In other respects their effects on smooth muscle are broadly similar but less marked than those of the Es. Other responses to PGEs include inhibition of gastric secretion, diuresis and natriuresis, inhibition of platelet aggregation $\left(\mathrm{E}_{1}\right)$, inhibition of lipolysis and a variety of CNS effects. In many respects the PGAs resemble PGEs in their biological effects, but lack many of the potent actions of the latter on metabolism and on non-vascular smooth muscle. Both PGFs and PGEs affect reproductive function in a variety of ways, and $\mathrm{PGF}_{2 \alpha}$ is notable for its capacity to induce luteolysis which has been demonstrated in all species studied except man and dog.

Endogenous PGs have, probably, a physiological role in the regulation of function in, e.g. the cardiovascular renal, gastro-intestinal, nervous and reproductive system, and an aetiological role in hypertension, peptic ulcer, diarrhoea and bronchial asthma.

The use of $\mathrm{PGF}_{2} \alpha, \mathrm{E}_{1}$ and $\mathrm{E}_{2}$ for the induction of labour and abortion in women depends in the main on their oxytocic activity but other factors may be involved. The use of $\mathrm{PGF}_{2 \alpha}$ for oestrous control in domestic animals depends on its luteolytic action. Analogues have been sought having increased luteolytic potency without a corresponding increase in tosixity. In a series of r6-aryloxyprostaglandins compounds with these characteristics - notably ICI 80,996 and ICI 8I,008 have been found. 


\section{INTRODUCTION}

Studies made independently in New York (KurzRok and LIEB, I930), London (GoldBlA'T', 1933 and I935) and Stockholm (Von EULER, I934 and I935) first revealed the presence in semen and extracts of male accessory glands of an acidic lipid which contracted smooth muscle and lowered blood pressure. This substance, which VoN EULER (I935) named " prostaglandin ", was later found to be a mixture of several closely related compounds and it was some 25 to 30 years before BERGSTRÖM and his colleagues isolated a number of its components and elucidated their structure (see BERGSTRÖM, I967). Further advances came with the synthesis of prostaglandins (PGs) from fatty acid precursors by incubation with homogenates of ram seminal vesicles (BERGSTRÖM et al., I964; VAN DORP et al., I964; WALLACH, I965) and with the development of total chemical syntheses of the natural PGs and many structural variants (BAGLI et al., I966; PIKE, I970 ; COREY, I97I). These events are tabulated b llow (table I).

TABLE I

\begin{tabular}{|c|c|}
\hline $1930-1935$ & $\begin{array}{l}\text { Active lipid factor in seminal fluid " prostaglandin " } \\
\text { (von Euler, 1935). }\end{array}$ \\
\hline Late $1950 \mathrm{~s}$ & Isolation and purification (BERGSTRöM, 1960). \\
\hline 1962 & Structure determined. \\
\hline 1964 & First Iaboratory synthesis (enzymatic). \\
\hline 1966 & Absolute stereochemistry established. \\
\hline & First chemical synthesis. \\
\hline
\end{tabular}

For many years, the small amounts of these materials available limited biological research to studies in laboratory animals and, in particular, experiments in vitro. However, work in the 1960 s led in rapid succession to the first successful use of $\mathrm{PGF}_{2 \alpha}, \mathrm{PGE}_{1}$ and $\mathrm{PGE}_{2}$ for the induction of labour (KARIM et al., I968b; EMBREY, I969 and 1970) and then of therapeutic abortion (KARIM and FILSHIE, I970 ; RoTHBRANDEI et al., I970) and raised hopes of their eventual use as " once-a-month " contraceptives (SPEIDEL and RAVENHOLT, I970). The discovery of the luteolytic activity of $\mathrm{PGF}_{2 \alpha}$ in laboratory animals (PHARRISS and WYNGARDEN, I969; BLATCHLEY and Donovan, I969) encouraged these hopes - and hinted at a new approach to oestrous control in domestic livestock (table 2), Meanwhile, observations in the

TABLE 2

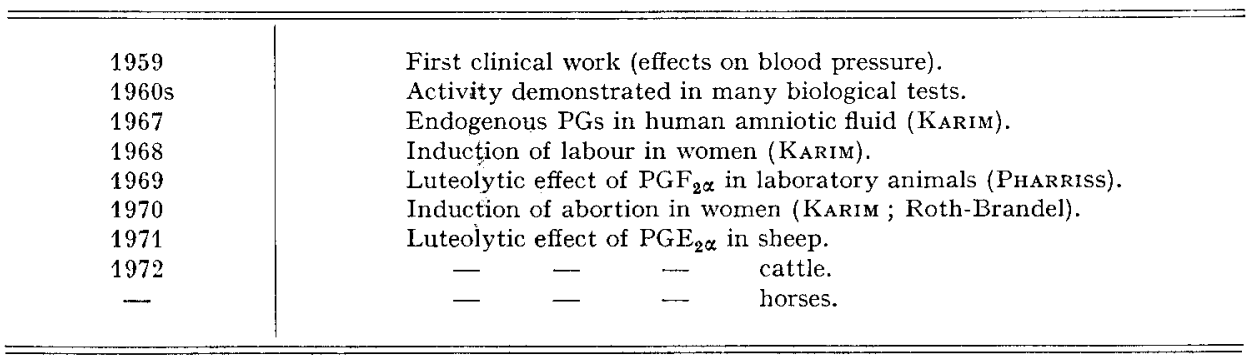


laboratory and clinic were suggesting that compounds of this class might have therapeutic applications in other directions, notably in bronchial asthma (CUTHBERT, r969 and I97I), hypertension (HINMAN, 1970) and peptic ulcers (WILsON et al., I970; CLASSEN et al., I970). The upsurge in research activity thus engendered, not least in the pharmaceutical industry, is reflected in the output of publications which, from being a mere trickle, became a veritable flood (fig. I). By I966, titles totalled about 400 ; by 1972 they had reached the 4,000 mark. The volume is now so vast that, even ignoring the trivial, it is impossible to be at once brief and comprehensive, and this paper is necessarily selective.

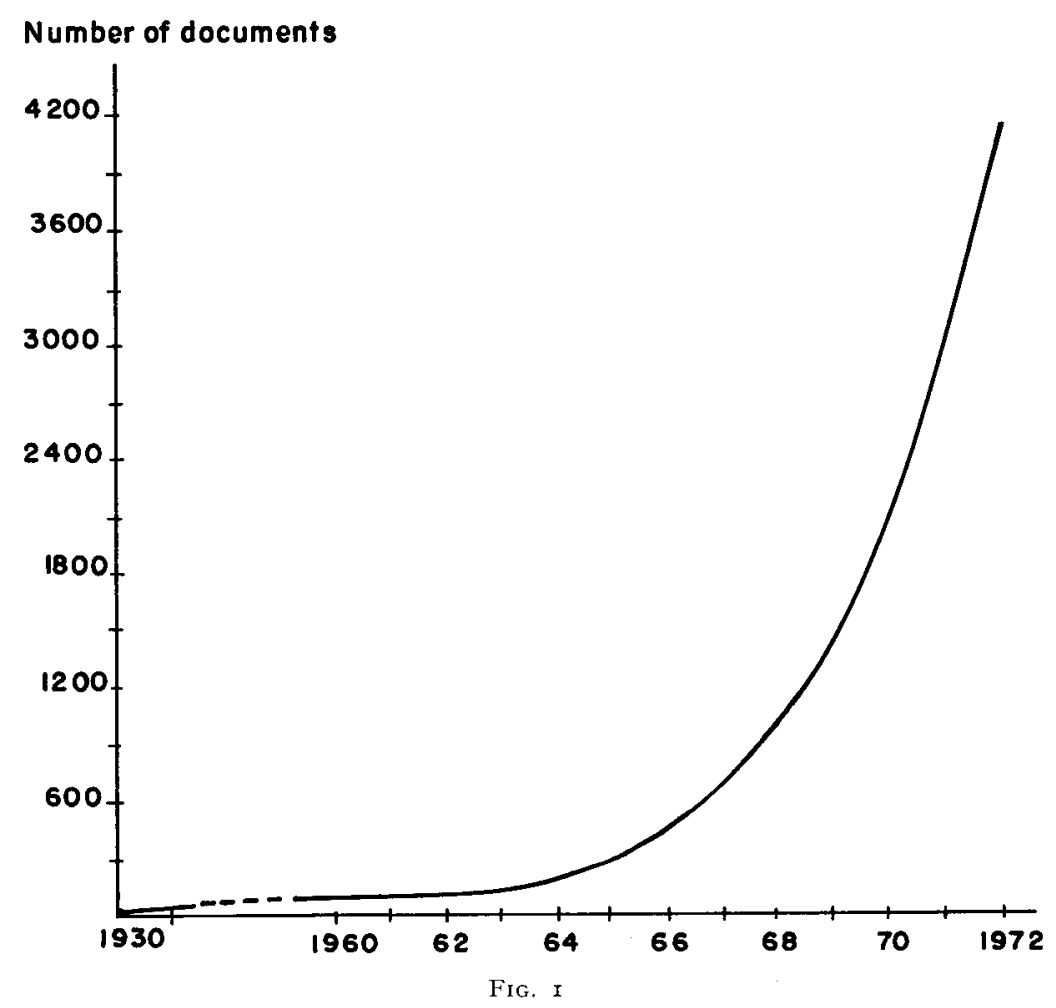

STRUCTURE

It is now known that there are 15 or so naturally occurring prostaglandins. They are all closely related in structure, being monocarboxylic acids of 20 carbon atoms containing a 5 membered ring with two adjacent side-chains, and can be looked on as derivatives of prostanoic acid (fig. 2). They fall into several series, designated by letter and distinguished by the substitution - pattern in the ring (fig. 3). Subscript numerals indicate the number of double bonds in the side chains and stereochemistry is 
represented conventionally, a broken line indicating that a group is below $(\alpha)$, and a continuous line that it is above $(\beta)$ the plane of the ring. Features common to all the natural substances are a trans double bond between C-I 3 and C-I4 and an $\alpha$ hydroxyl group at C-I5. Compounds which in structure resemble the natural PGs in some respects but differ from them in others are usually called analogues, but the term prostaglandin is often used - and "prostenoid» less frequently — to include these synthetic variants.

\section{Prostanoic Acid}

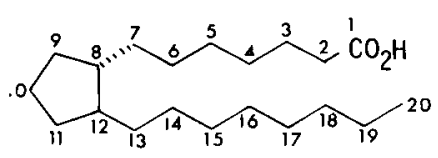

FIG. 2

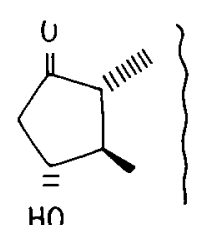

$\mathrm{HO}$

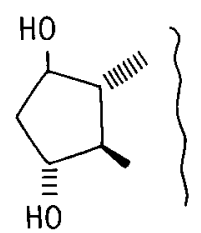

$F$

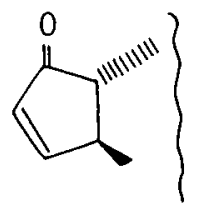

A

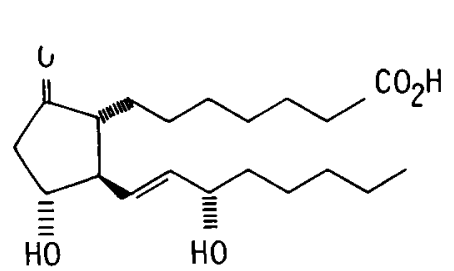

$\mathrm{PGE}_{1}$

HO

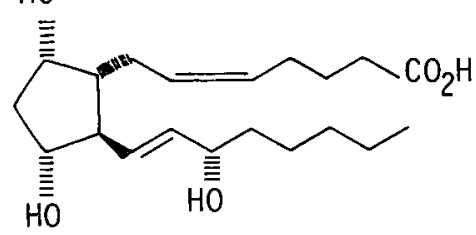

$\mathrm{FGF}_{2 \alpha}$

FIG. 3

Prostaglandins of the $F$ and $E$ series, and particularly $F_{2 \alpha}, E_{1}$ and $E_{2}$ have received more attention than any others. $\mathrm{PGF}_{2 \alpha}$, with $\alpha$-hydroxyl groups at $\mathrm{C}-9$ and $\mathrm{C}$-II is a fairly robust molecule. It is soluble in alcohol or, as the sodium or tromethamine (THAM) salt, in water and is stable in solution. The PGEs, with have a keto group in place of hydroxyl at $\mathrm{C}-9$, are less stable. With weak alkali they readily lose the elements of water to give the corresponding PGAs from which the PGBs can be obtained by a shift of the double bond to the C-8, I2 position in the ring. 


\section{DISTRIBUTION}

Prostaglandins in varying amounts and proportions have been found in almost all the tissues of the mammalian body : in a number of instances they are released when tissues are stimulated or activated. Once in circulation they are very rapidly metabolised and hence they must be formed in many sites.

Human seminal plasma is the richest source in which, by I966, thirteen different PGs had been identified $\left(\mathrm{E}_{1}, \mathrm{E}_{2}, \mathrm{E}_{3}, \mathrm{~F}_{1 \alpha}, \mathrm{F}_{2 \alpha}, \mathrm{A}_{1}, \mathrm{~A}_{2}, \mathrm{~B}_{1}, \mathrm{~B}_{2}\right.$ and Iq-hydroxy $\mathrm{A}_{1}, \mathrm{~A}_{2}$, $B_{1}$ and $B_{2}$ ) in a total concentration of about $300 \mu \mathrm{g} / \mathrm{ml}$ (HAMBERG and SAMUELSSON, I966; Bygdeman and Samuelsson, I966). Only recently two new PGs, Ig-hydroxy $E_{1}$ and $E_{2}$, have been found in human semen, where they total Ioo $\mu \mathrm{g} / \mathrm{ml}$ (TAYLOR and KELLY, I974). Fewer are present in the seminal fluid of other species, and none has yet been found in porcine semen. The distribution of PGs in the tissues varies widely among the species, and in most sites outside the reproductive system the amounts found are very small - to be reckoned in $\mathrm{ng} / \mathrm{g}$ (see, e.g., KARIM et al., I967; Ig68 a).

\section{Biosynthesis of Prostaglandins}

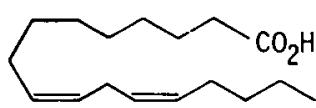

Linoleic acid

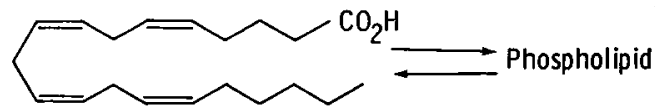

Arachidonic acid

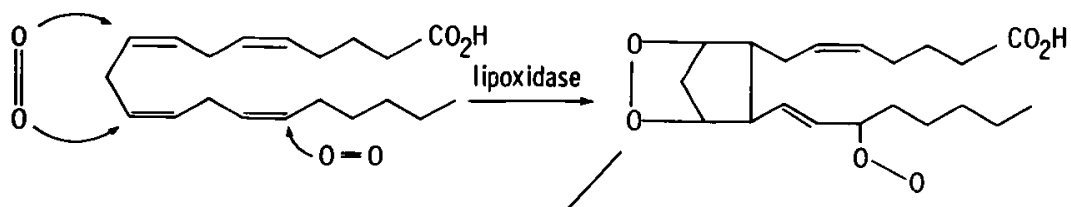

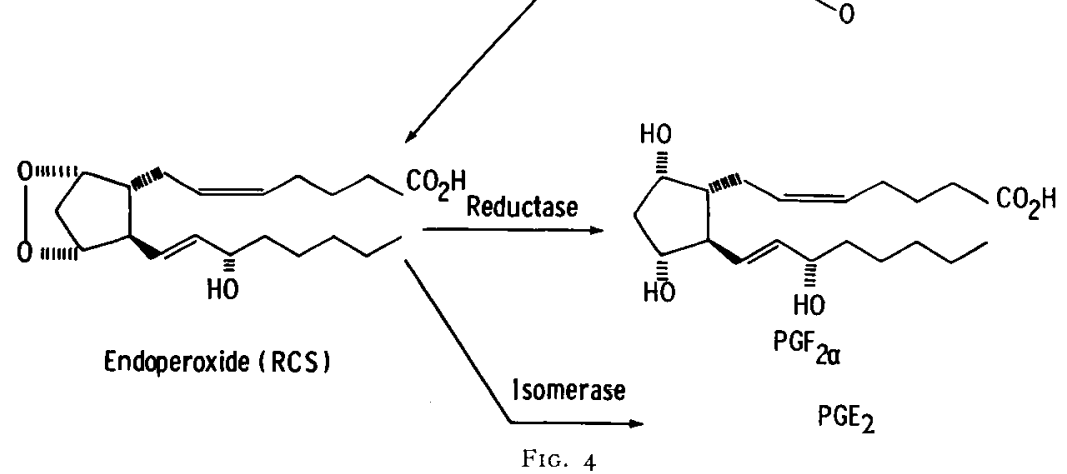




\section{BIOSYN'THESIS}

The elucidation of the main features of the biosynthesis of the natural PGs marked an important advance in this field of research (fig. 4). The starting point is the essential dietary constituent, linoleic acid which is readily converted in the body to other unsaturated fatty acids - for example, arachidonic. This acid, stored in the tissues as a phospholipid and regenerated on demand, is the precursor from which PGs with 2 double bonds are formed by enzymatic processes via a peroxy intermediate and a bicycle peroxide (RCS). PGs with $\mathrm{I}$ or 3 such bonds arise by analogous biosynthetic processes from unsaturated fatty acids related to arachidonic.

Prostaglandin-synthetase systems are found in many tissues. These include the seminal vesicles (those of the ram and goat have been used for the preparation of PGs for laboratory and clinical use) and also other tissues such as lung, brain, intestinal mucosa, and renal medulla. The suggestion has been made that the synthetase cofactors locally available in specific tissues may affect the E/F ratio of the PGs formed.

\section{METABOLISM}

Prostaglandins are not stored in the tissues and those of the $\mathrm{E}$ and $\mathrm{F}$ series are rapidly removed from the circulation by metabolic degradation (fig. 5 and 6 ). This involves successive attack at four points in the molecule, viz., dehydrogenation at $\mathrm{C}-\mathrm{I} 5$, reduction of the $\mathrm{C}-\mathrm{I} 3, \mathrm{I} 4$ double bond, $\beta$-oxidation (twice) of the upper side chain, reducing it in length to 4 carbon atoms, and oxidation of the terminal methyl group at $\mathrm{C}-20$ to carboxyl. The first two of these steps are very rapid, 15-dehydrogenation more so than $\mathrm{I}_{3}$, I4 reduction, and occur mainly, though not exclusively, in the lungs. As much as $98 \mathrm{p}$. Ioo of the biological activity of the PGEs and PGFs is lost during a single passage through the pulmonary circulation (VANE, Ig69) but although, generally speaking, the products of these first two stages of catabolism are low in biological potency, there are exceptions to this. Thus $\mathrm{I}_{5}$-keto $\mathrm{PGF}_{2 \alpha}$ is more potent than $\mathrm{PGF}_{2 \alpha}$ in contracting several types of smooth muscle and, in particular, is a very potent bronchoconstrictor (DAwson et al., 1974) and while dihydro-I5-keto $\mathrm{PGF}_{2 \alpha}$ has little spasmogenic activity on many tissues (PIKE et al., I967), it is a very powerful stimulant of uterine muscle (HILLIER, personal communication). However, such intermediary metabolites have only a transient existence in the blood-stream, since the last two steps in catabolism are also rapid. These occur in the liver; they lead to the final products shown in figures 5 and 6 which are biologically inactive and are the final urinary excretion products in man.

Figure 7 summarises, in outline, the biosynthesis and metabolism of $\mathrm{PGE}_{2} \alpha$ and $\mathrm{PGF}_{2 \alpha}$. (For a more detailed account of this topic, see SAMUELSSON, I973).

It is noteworthy that PGs of the A series are not inactivated by passage through the lungs (HORTON and JONES, I969) and persist for longer in the general circulation.

From the foregoing it will be evident that such physiological actions as endogenous PGEs and PGFs may exert will be limited to the proximity of their sites of 


\section{Metabolism ( PGE 2)}
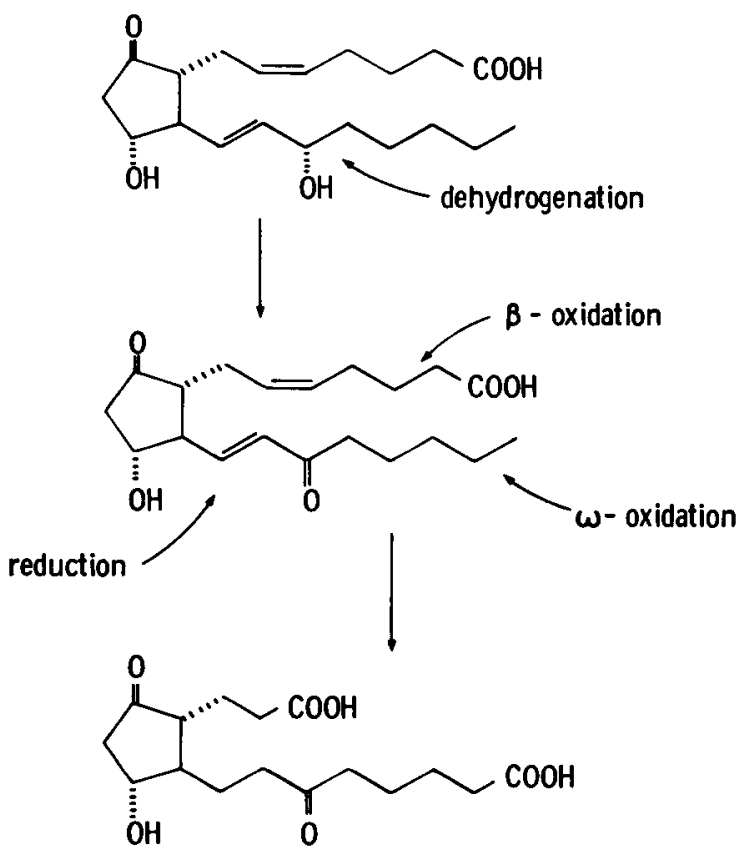

FIG. 5

\section{$\underline{P G F} \underline{2 \alpha}$}
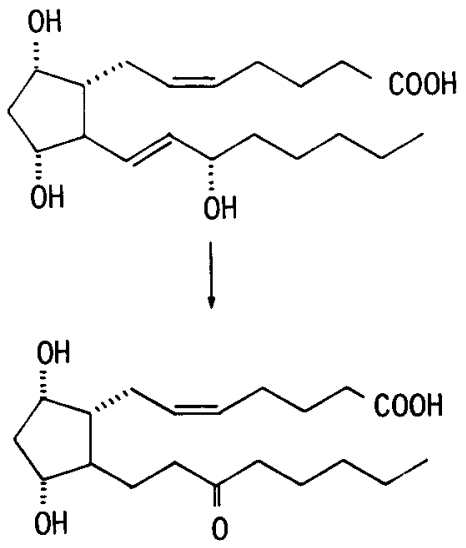

15 - keto - dihydro - PGF $2 \alpha$

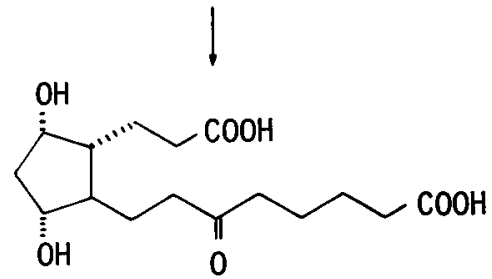

FIG. 6. - Metabolism of $P G F_{2 \alpha}$ 
production by their rapid inactivation on reaching the general circulation. They may thus be regarded as local hormones, in contrast to the PGAs which have more claim to the status of hormones as usually understood.

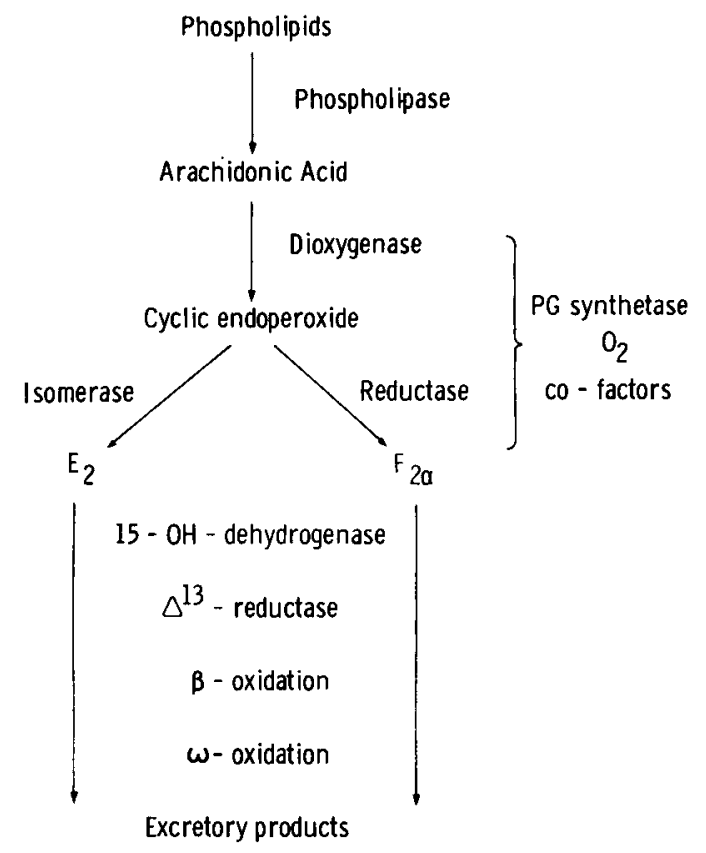

Fig. 7. - Biosynthesis and Metabolism of $P G E_{2}$ and $P G F_{2 \alpha}$ (summary)

\section{BIOLOGICAL, EFFECTS}

The ubiquitous distribution of prostaglandins suggests that they have a part to play in many physiological and, perhaps, pathological processes. Information from studies of various kinds indicates what their roles may be. It comes in part from studies of the biological or, more properly, pharmacological effects of these agents both in vitro and in vivo ; in part from studies of the effects of substances, such as indomethacin, known to inhibit their biosynthesis (VANE, I97I), as well as of prostaglandin antagonists, e.g. 7-oxa-I3-prostynoic acid (FRIED et al., I969), and more recently of antigenic conjugates of PGs (SCARAMuzzI et al., I973); and partly from measurements of the concentration of $\mathrm{PGs}$ in various tissues of the body in various physiological states in health and disease.

Table 3 summarises, however imperfectly, some of the pharmacological effects of PGs outside the reproductive system. Generalisation is difficult, since responses are often species dependent and may even vary from one part of an organ to another as, for example, between longitudinal and circular smooth muscle of the intestine (see below). Nevertheless, the remarkably wide range of responses evoked is clearly apparent. A further point to be stressed is the high potency of these agents in several respects. 
TABLE 3

Biological effects of natural prostaglandins

Cardiovascular system

Respiratory system

Alimentary system

Cardiac sphincter

Stomach

Intestine

Renal system

Platelets

Thyroid

C. N.S. decrease arterial and venous pressure (Es, [A])

dilate (Is) or constrict (Fs)

contract $\left(\mathrm{F}_{2 \alpha}\right)$ or $\operatorname{relax}\left(\mathrm{E}_{\mathbf{2}}\right)$

inhibit gastric secretion ( $\mathrm{Es},[\mathrm{A}]$ )

increase motility and fluid content of lumen

stimulate diuresis and natriuresis ( $\mathrm{Es},[\mathrm{A}]$ )

inhibit aggregation $\left(E_{1}\right)$

promote hormonogenesis

cause sedation, pyrexia etc.

Broadly speaking the effects of the PGEs are more consistent and more pronounced than those of $F_{2 \alpha}$.

Prostaglandins E (and A), given intravenously, lower blood pressure in many species, including man and dog. This is attributed to their vasodilatory action in which respect they are among the most potent substances known. At the same time they have a direct action on the heart, increasing heart rate and cardiac output (see BERGSTRÖM ct al., I968). PGFs, on the other hand, cause different responses in different species. They lower blood pressure in cats and rabbits, but are pressor in rats and dogs, where the rise in blood pressure is due to increased cardiac output brought about by venoconstriction and an increased venous return. It is significant that PGE,s, which in general cause vasodilation, can have the reverse effect in at least one vascular bed. $\mathrm{PGE}_{1}$ and $\mathrm{PGE}_{2}$ have been found to be equiactive with noradrenaline in constricting the blood vessels of the nasal mucosa of dogs, and in the same dose as the catecholamine $(5 \mu \mathrm{g} / \mathrm{kg}$ ) have an effect lasting 7 times as long (S'TOVALI and JAcKson, I967). Comparable effects have been described on the nasal mucosa of human volunteers (ÄNGGÅRD, Ig69).

Several of the more pronounced effects of PGEs and PGFs involve actions upon smooth muscle, including that of the gastro-intestinal and respiratory tracts. PGs of both series contract isolated segments of longitudinal smooth muscle from various levels of the gastro-intestinal tract of many species. Some preparations are extremely sensitive - for example, guinea-pig colon is contracted by $\mathrm{PGE}_{1}$ in concentrations of less than $0.5 \mathrm{ng} / \mathrm{ml}$ - and some (guinea pig ileum, gerbil colon, rat fundic strip) have been used for the routine bioassay of PGs. On such preparations, in general, potencies are in the order $\mathrm{PGE}_{2}>\mathrm{PGE}_{1}>\mathrm{F}_{2 \alpha} . \mathrm{PGF}_{2 \alpha}$ also causes contraction of gastro-intestinal circular smooth muscle, but the PGEs produce relaxation of this tissue (BENNETT et al., Ig68).

It seems likely that the effects of PGs on gastro-intestinal smooth muscle account in part for their tendency in several species, including man, to provoke abdominal colic and (watery) diarrhoea. A further contributing factor is the massive flux of fluid and electrolytes, provoked by these agents, into the lumen of the gut (GREENOUGH et al., Ig69; Cummings et al., I973). 
Prostaglandins $\mathrm{E}_{1}$ and $\mathrm{E}_{2}$ relax smooth muscle of the respiratory tract of several species. They reduce the inherent tone of human bronchial strips in vitro - $\mathrm{PGE}_{1}$ at a concentration of $0.25 \mu \mathrm{g} / \mathrm{ml}$ (SHEARD, I968) - and inhibit the spasmogenic action thereon of histamine. $\mathrm{PGF}_{2 \alpha}$ has a weak relaxing effect in some species, but contracts human bronchial muscle (SwEATMAN and COLIIER, I968) and may induce bronchospasm in susceptible individuals.

In addition to the actions already touched upon, $\mathrm{PGE}_{1}$ is a potent inhibitor of lipolysis as was demonstrated in vitro by STEINBERG et al., as early as I963. However, when given intravenously in low doses to dogs or humans, it causes a reflex stimulation of the sympathetic nervous system and the net effect is a stimulation of lipolysis with increases in the concentration of free fatty acids, glycerol - and glucose in the blood. Higher doses, not tolerated by man, reduce basal lipolysis in dogs. (See BERGSTRÖM et al., rg68).

As to the fundamental mode of action of PGs, only two points will be made here. First, specific membrane bound receptors have been demonstrated in several cell types - as, for example, (for Es) in lipocytes (KUEHL and HUMES, I972) and (for Fs) in cells from the corpora lutea of several species (PowELL et al., I974) : second, it seems to involve interaction with the adenyl cyclase (Es) and guanyl cyclase (Fs) systems (KUEHL, I973).

\section{PHYSIOLOGICAL AND PATHOGENIC ROLES}

Table 4 indicates some of the more plausible of the functions (again excluding reproduction) that have been suggested for endogenous prostaglandins in health and disease. It must be admitted that the evidence that the PGs have any such role is still largely circumstantial and there are those who hold the view that they play little part in the maintenance of normal physiological function. This view is supported by an observation reported by SAMUELSON at the International Prostaglandin

TABLE 4

Roles of prostaglandins

\section{Physiological}

Modulate control of systemic blood pressure and sodium and water homeostasis (via cardiovascular and renal effects).

Regulate intestinal muscle-tone.

Modulate central and autonomic nervous transmission.

2. Pathological

Aetiological role in,

- hypertension

- gastric hypersecretion, ulcers

- diarrhoea (e.g. cholera)

- bronchial asthma

Mediators of inflammation (pain) and pyrexia. 
Conference in Vienna in September, 1972. He found that prostaglandin production could be virtually arrested in human volunteers by continuous treatment with indomethacin, with no apparent effect upon their health.

\section{REPRODUCTION}

There is now little doubt, however, that endogenous PGs are involved in reproductive processes, certainly in the female of several species and possibly also in the male. It is fairly generally accepted that luteolysis in the cycling sheep, cow and guinea-pig and possibly also in the pig, hamster and horse is mediated by $\mathrm{PGF}_{2 \alpha}$ though the mechanism of prostaglandin-induced luteolysis is still a matter of debate. Prostaglandins are also certainly involved in normal parturition (ChaLLIS, 1974) and there is increasing evidence that they have a physiological role in ovulation (see Behrman and Anderson, I974; Armstrong, this volume p. IOo). Studies of the pharmacological effects of $\mathrm{PGs}$ on reproductive function in the female and, to a lesser extent in the male, have been pursued with vigour in several species. Both physiological and pharmacological aspects have been the subject of many symposia and reviews (e.g. Speroff and Ramweil, i970; Behrman and ANDFrson, I974; Pharriss and Shaw, I974) and receive some attention elsewhere in this volume.

Of paramount interest in the context of the present colloquium is the luteolytic activity of $\mathrm{PGF}_{2}$ which has been demonstrated, in appropriate circumstances, in every species studied (PHARRIss et al., 1972) with possible exception of man, and dog (JöCHLE et al., I973). However, the first clinical use of prostaglandins and still the only one of established practical utility, i.e. use of these agents for terminating human pregnancy, is based on their stimulant action on uterine smooth muscle.

\section{CI,INICAI, APPI,ICATION}

Early studies by BYGDEMAN (I964) among others showed that, in vitro, $\mathrm{PGF}_{\mathbf{2} \alpha}$ stimulates contraction of the non-pregnant and pregnant human myometrium, whereas PGEs relax the non-pregnant, and have a variable effect on the pregnant human uterine muscle. It was only later established (BYGDEMAN et al., I968) that, when injected intravenously into pregnant women, PGEs regularly cause strong contractions. This is now known to be true of PGs of both series, at all stages of pregnancy. In this important respect the prostaglandins differ from oxytocin which is effective only in late pregnancy.

Meanwhile, KARIM and DEVIIN (I967) had found significant amounts of PGF ${ }_{2 \alpha}$ (and traces of Es) in amniotic fluid from women in labour at term and during spontaneous abortion. This prompted clinical studies leading to the first successful induction of labour and delivery with $\mathrm{PGF}_{2} \alpha$, given by slow intravenous infusion (KARIM et al., I968 b). Similar results were reported with $\mathrm{PGE}_{1}$ and $\mathrm{E}_{2}$ and before long it was found that any of these three PGs, in appropriate dosage, would also induce abortion in a proportion of women in the second and first trimesters of pregnancy (for references, see Introduction).

Table 5 shows in rounded figures the kind of schedules found effective in early 
trials. It is evident the $\mathrm{PGE}_{2}$ is more potent than $\mathrm{F}_{2}$ in terminating pregnancy at any stage, and that when given systemically, both are more potent in inducing labour than abortion. In the past few years much clinical work has been done in this area, particularly with $\mathrm{PGF}_{2}$ and $\mathrm{E}_{2}$ which are now available commercially for human use. The results of many of these studies have been summarised by BYGDEMAN et al., (1973) who also discuss the advantages and drawbacks of the use of these agents compared with other methods of inducing labour and abortion (see also BEHRMAN and ANDerson, I974 and Pharriss and SHaw, I974). Altough it is still too early to make a final assessment of their place in obstetrics, $\mathrm{PGF}_{2 \alpha}$ or $\mathrm{E}_{2}$ are now in routine use in some departments for these purposes. For abortion some favour intra-amniotic, and some intra-uterine (extra-ovular) administration : both procedures largely obviate the side-effects of intravenous infusion. Nevertheless, success is not invariable and side-effects and complications still cause some concern - hence the continuing interest in analogues which might have better margins of tolerance (see below).

It should be noted that underlying the procedures commonly employed in the abortifacient use of prostaglandins is the tacit assumption that they necessarily act in all circumstances by directly stimulating myometrial activity, i.e., as oxytocics. Hence by whatever route they are given, emphasis is on continued or repeated administration, the object being — while avoiding hypertonus - to initiate myometrial activity and to maintain it until the conceptus is expelled.

TABLE 5

Prostaglandins : termination of human pregnancy

\begin{tabular}{|c|c|c|c|}
\hline \multirow{2}{*}{ Induction of : } & \multirow{2}{*}{ Route } & \multicolumn{2}{|c|}{ Dosage : rate and (total) } \\
\hline & & $\mathrm{F}_{2}$ & $\mathrm{E}_{2}$ \\
\hline \multirow{2}{*}{$\begin{array}{c}\text { Labour } \\
(35 \text { weeks } \rightarrow)\end{array}$} & $\begin{array}{l}\text { i.v. } \\
\text { infusion }\end{array}$ & $\begin{array}{l}2.5 \mu \mathrm{g} / \mathrm{min} \\
(\approx 6 \mathrm{mg})\end{array}$ & $\begin{array}{l}0.5 \mu \mathrm{g} / \mathrm{min} \\
(\approx 0.2 \mathrm{mg})\end{array}$ \\
\hline & oral & $\begin{array}{c}5 \mathrm{mg} / 2 \mathrm{hr} \\
(\approx 25 \mathrm{mg})\end{array}$ & $\begin{array}{l}0.5 \mathrm{mg} / 2 \mathrm{hr} \\
(\approx 2.5 \mathrm{mg})\end{array}$ \\
\hline \multirow{2}{*}{$\begin{array}{c}\text { Abortion } \\
(6-28 \text { weeks })\end{array}$} & $\begin{array}{l}\text { i.v. } \\
\text { infusion }\end{array}$ & $*\left[\begin{array}{ll}50 & \mu \mathrm{g} / \mathrm{min} \\
(\approx & 50 \mathrm{mg})\end{array}\right]$ & $\begin{array}{l}5 \mu \mathrm{g} / \mathrm{min} \\
(\approx 5 \mathrm{mg})\end{array}$ \\
\hline & $\begin{array}{l}\text { intra-uterine } \\
\text { infusion }\end{array}$ & $(\approx 2.5 \mathrm{mg})$ & (1.2 mg) \\
\hline $\begin{array}{l}\text { Abortion } \\
v \text {. early }\end{array}$ & intravaginal & $\begin{array}{l}50 \mathrm{mg} / 4 \mathrm{hr} \\
(\approx 100 \mathrm{mg})\end{array}$ & $\begin{array}{l}20 \mathrm{mg} / \mathrm{thr} \\
(\approx 40 \mathrm{mg})\end{array}$ \\
\hline re & cts & & \\
\hline
\end{tabular}

A different approach has been developed by CSAPO, who has shown that abortion can be reliably induced with a single large dose of prostaglandin administered, over a period of ca. Io mn., directly into the uterus of sedated patients. By 
this procedure abortion was achieved (under the euphemism of " menstrual induction ") in 97 out of 100 women given $5 \mathrm{mg}$ of $\mathrm{PGF}_{2 \alpha}$ (or I $\mathrm{mg}$ of $\mathrm{E}_{2}$ ) as early as II $\mathrm{I}$ days after missed menstruation. The technique was also used sucessfully - with larger doses of prostaglandin - to terminate pregnancy throughout the broad gestational range of 7 to 20 weeks.

CsAPO believes that an essential feature of the action of prostaglandins, used in this way, is impairment of the endocrine function of the conceptus, brought about by the combined effect of venoconstriction in the uterine microcirculation and sustained uterine spasm. This in turn leads, directly or indirectly, to progesteronewithdrawal which reduces the threshold of excitability of the myometrium. The uterus now responds to the stimulus of endogenous prostaglandin with the progressive evolution of cyclical intrauterine pressure changes culminating in abortion.

Up to about 2I days after missed menstruation ( 5 weeks after ovulation) the corpus luteum is indispensable as a source of progestetone for the maintenance of pregnancy. During this time, however, luteal function is critically dependent on the luteotrophic support of the placenta. Up to this time, prostaglandin-induced impairment of feto-placental endocrine function will lead indirectly to progesteronewhithdrawal; after this time, when the placenta alone produces sufficient progesterone to maintain pregnancy, progesterone-withdrawal will result directly from impairment of feto-placental function.

Such, then, is a brief summary of CSAPo's work and views as expounded by him, with supporting documentation, in a recent publication (CSAPo, I974).

Whatever the truth of the matter, it seems very unlikely that luteolysis, brought about by a direct action at the ovarian level, plays any part in the abortifacient action of the natural prostaglandins in man. Indeed, there is no convincing evidence that $\mathrm{PGF}_{2 \alpha}$ is luteolytic in the pregnant human female, while attempts to shorten the luteal phase of the menstrual cycle by its administration have been consistently disappointing (see Pharriss and Shaw, I974). When PGF $_{2 \alpha}$ was given at high rates of infusion and for relatively long periods of time, a transient decrease in progesterone secretion was observed, with slight bleeding but no premature menstruation, and even this result could not be achieved without the accompaniment of quite unacceptable side-effects. Nevertheless the hope persists that a prostaglandin analogue may be found which is luteolytic in women and sufficiently well tolerated to precipitate menstruation when given at the end of each month, irrespective of wether or not the woman is pregnant-and hence to be used as the long sought " oncea-month " contraceptive.

\section{PROSTAGI,ANDIN ANALOGUES}

Exploitation of the natural PGs for the regtrlation of fertility, particularly in the human, is limited by side-effects, chief among which are the gastrointestinal. Many analogues have now been synthesized with the object of increasing potency and, hopefully, acceptability. On the premise that potency will be increased by increased persistence in the body, analogues have been made in which resistance to the first stage in metabolic inactivation has been achieved by introducing "blocking " 
groups at C-I5 or C-I6 in the prostaglandin molecule (see PIKE, I973). Compounds of this type, e.g., I5-methyl-and I6,-I6-dimethyl-PGF ${ }_{2 \alpha}$, have indeed been found to have greatly increased potency in vivo. Preliminary clinical assessment suggests that with the former, midtrimester abortion can be achieved by intra-amniotic injection of a single dose of $5 \mathrm{mg}$ (BYGDEMAN et al., I973).

In the laboratories of ICI a more empirical approach has been adopted to the problem, specifically, of increasing luteolytic potency without increasing smooth muscle-stimulating activity to a corresponding extent, and preferably reducing it. My colleagues in the chemistry department, led by Dr. Neville Crossley, have prepared a series of I6-aryloxy analogues of PGF PG $_{2 \alpha}$ (BINDER et al., I974) some of which show greatly increased luteolytic potency with relatively reduced " smooth muscle activity " - and toxicity (Dukes et al., I974). This is illustrated by the results of laboratory assessment shown in tables 6,7 and 8 . Some studies of the applications

TABLE 6

Structure of some analogues of $P G F_{2 \alpha}$, and minimum doses needed to terminate early pregnancy in hamsters (luteolytic effect)

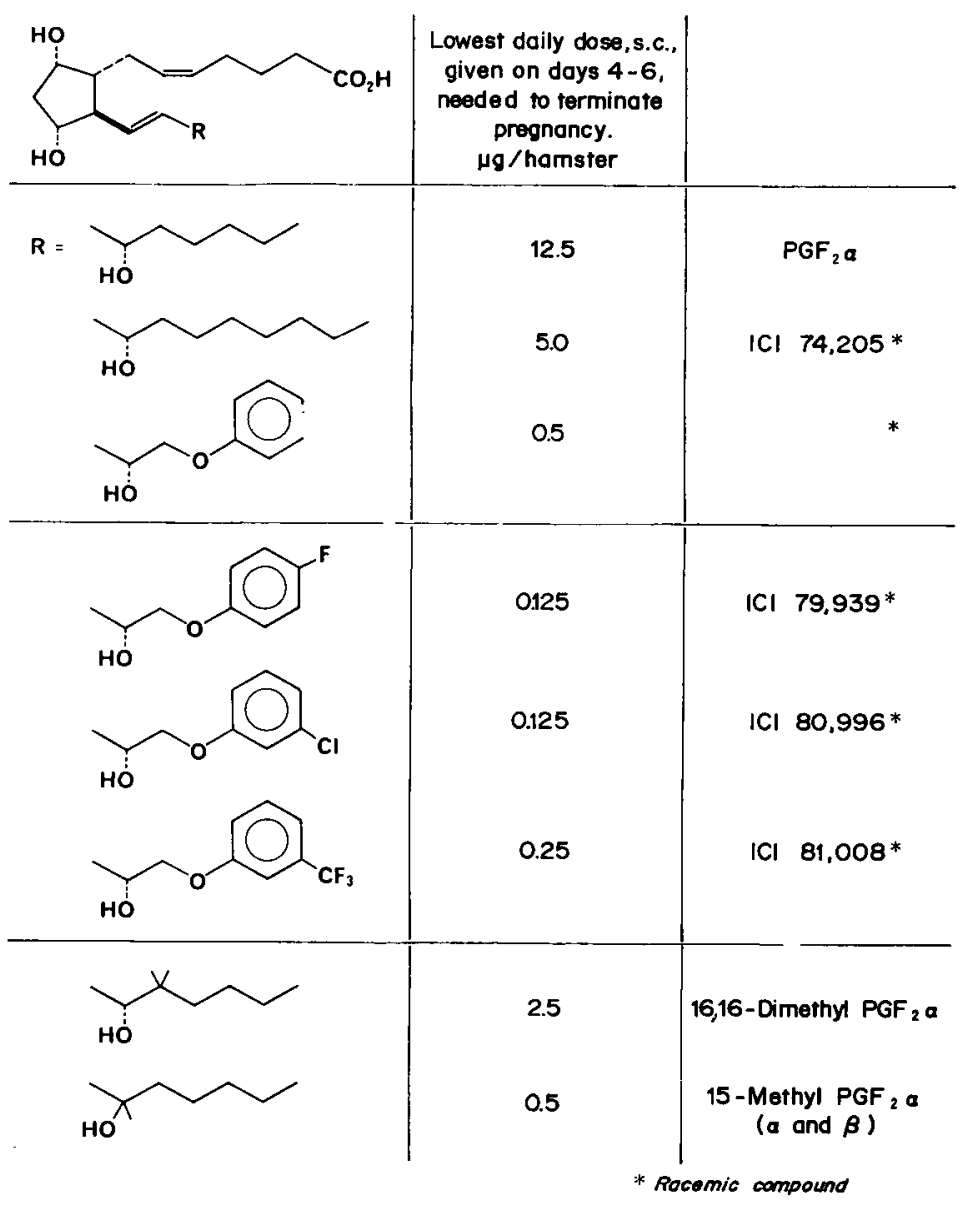


TABLE 7

Relative potencies of some prostaglandins

in stimulating contractions of smooth muscle in vitro

\begin{tabular}{l|l|l}
\hline Compound & Guinea-pig uterus & Gerbil colon \\
\hline & 1 (assigned) & 1 (assigned) \\
PGF $_{2}$ & 10 & 9.5 \\
ICI 79,939 & 1 & 0.6 \\
ICI 80,996 & 0.02 & 0.036 \\
ICI 81,008 & 36 & - \\
PGE & & \\
\hline
\end{tabular}

TABLE 8

Doses of $P G F_{\mathbf{2}}$ and analogues which cause diarrhoea in young male rats

\begin{tabular}{c|c|c}
\hline Compound & Dose $(\mu \mathrm{g} / \mathrm{kg})$ & Incidence of diarrhoea \\
\hline PGF $_{2 \alpha}$ & $\begin{array}{r}120-240 \\
1,000\end{array}$ & $\begin{array}{c}50 \% \text { of rats } \\
100 \%\end{array}$ \\
\hline ICI 79,939 & 100 & $\begin{array}{c}\text { acutely lethal } \\
50 \% \text { of rats } \\
100 \%\end{array}$ \\
\hline ICI 80,996 & $\begin{array}{c}1,000 \\
2,400\end{array}$ & \begin{tabular}{c} 
no side-effects seen \\
\hline ICI 81,008
\end{tabular} \\
\hline
\end{tabular}

of ICI 79,939, ICI 80,996 and ICI $8 \mathrm{I}, 008$ (Equimate) in the control of oestrus in domestic species are described elsewhere in this volume : their potential in the field of human reproduction awaits clinical evaluation.

Colloque : Control of sexual cycles in domestic animals October 27-30, 1974, Nouzilly.

\section{RÉSUMÉ}

\section{CARACTÉRISTIQUES DES PROSTAGLANDINES}

Les prostaglandines naturelles (PGs) sont toutes des acides hydroxylés insaturés de 20 atomes de carbone centrés sur un noyau cyclopentagonal avec 2 chaînes latérales adjacentes. Il y en a 4 séries principales, désignées E, F, A et B, ayant des différences dans le noyau. On les trouve dans de nombreux tissus de Mammifères mais en très basse concentration excepté dans lefluide séminal de certaines espèces, l'espèce humaine incluse. Au moins I5 PGs ont été identifiées jusqu'à maintenant, avec une concentration totale de $300 \mu \mathrm{g} / \mathrm{ml}$ dans le sperme humain qui est la source la plus riche. Les PGs sont formées dans de nombreux tissus, souvent en réponse à une stimulation, par biosynthèse à partir d'acides gras insaturés, comme l'acide arachidonique. Les PGFs et les PGEs libérées dans la circulation sont rapidement métabolisées, principalement dans le poumon 
et le foie en produits d'excrétion urinaire inactifs. Les PGAs sont moins rapidement inactivées.

Les PGs ont un champ d'activités pharmacologiques remarquablement large, activités dans lesquelles elles sont souvent extrêmement puissantes. Les produits des différentes séries montrent diverses spécificités d'action et les réponses pharmacologiques dépendent souvent des espèces. Les PGEs diminuent habituellement la pression sanguine, stimulent les muscles gastro-intestinaux ou utérins et relâchent les muscles lisses de la respiration. Les PGFs au contraire augmentent la pression sanguine chez certaines espèces et dans quelques cas provoquent une broncho-constriction. Par ailleurs leurs effets sur les muscles lisses sont très semblables quoique moins marqués que ceux des PGEs. Parmi les autres réponses aux PGEs on trouve l'inhibition de la sécrétion gastrique, la diurèse et la natriurèse, l'inhibition de l'aggrégation des plaquettes $\left(E_{1}\right)$, l'inhibition de la lipolyse et divers effets sur le système nerveux central. A de nombreux égards les PGAs ressemblent aux PGEs quant à leurs effets biologiques mais ne possèdent pas les puissantes actions de ces dernières sur le métabolisme et sur les muscles lisses non vasculaires. Les deux catégories de prostaglandines, PGFs et PGEs, affectent la reproduction de différentes façons ; $\mathrm{PGF}_{2} \alpha$, en particulier induit la lutéolyse dans toutes les espèces étudiées, l'espèce humaine et l'espèce canine exceptées.

Les prostaglandines endogènes ont probablement un rôle physiologique dans la régulation des systèmes cardiovasculaire, rénal, gastro-intestinal, nerveux et reproducteur. Elles ont un rôle éthiologique dans l'hypertension, l'ulcère pepsique, la diarrhée et l'asthme bronchique.

L'utilisation des $\mathrm{PGF}_{2}, \mathrm{E}_{1}$ et $\mathrm{E}_{2}$ pour induire la parturition et l'avortement chez la femme dépend principalement de leur activité ocytocique mais d'autres facteurs peuvent être impliqués. L'utilisation de $\mathrm{PGF}_{2} \alpha$ pour le contrôle du cycle œestrien chez les animaux domestiques dépend de son action lutéolytique. On a recherché des analogues ayant une puissance lutéolytique accrue sans augmentation correspondante de la toxicité. Des composés avec de telles caractéristiques notamment ICI 80996 et ICI 8I 008 ont été trouvés dans la série des 16 -aryloxyprostaglandines.

\section{REFERENCES}

ANGGARD A., 1969. The effect of prostaglandins on nasal airway resistance in man. Ann. Otol. Rhinol. Laryngol., 78, 657-662.

Bagli J. F., Bogri T., Deghenghi R., Wiesner K., I966. Prostaglandins, I-Total synthesis of $9 \beta$, I $5 \varepsilon$-dihydroxyprost-I3-enoic acid. Tetrahedron Lett., 5, 465-470.

Behrman H R., Anderson G. G., I974. Prostaglandinsinreproduction. Arch.intern. Med., 133,77-84. Bergström S., x967. Prostaglandins : members of a new hormonal system. Science, 15\%, 382-39r.

Bergström S., Danielsson H., Samuelsson B., ig64. The enzymic formation of prostaglandin $\mathrm{E}_{2}$ from arachidonic acid. Biochem. Biophys. Acta, 90, 207-2 Io.

Bergström S., Carlson L. A., Weeks J. R., I968. The prostaglandins : a family of biologically active lipids. Pharmac. Rev., 20, I-48.

Bennett A., Murray J. G., Wyllit J. H., ig68. Occurrence of prostaglandin $E_{2}$ in the human stomach and a study of its effects on human isolated gastric muscle. Br.J. Pharmac. Chemother., 32, 339-349.

Binder B., Bowler J., Brown E. D., Crossley N.S., Hutton J., Senior M., Siater L., Wil,KINSON P., Wright N. C. A., I974. I6-Aryloxyprostaglandins: a new class of potent luteolytic agent. Prostaglandins, 6, 87-90.

Blatchley F. R., Donovan B. T., 1969. Luteolytic effect of prostaglandin in the guinea pig. Naturc (Lond.), 221, I065-Io66.

Bygdeman M., I g64. The effect of different prostaglandins on the human myometrium in vitro. Acta Physiol. Scand., Suppl., 242, I-78.

Bygdeman M., Samuelsson B., I966. Analysis of prostaglandins in human semen. Clin. Chim. Acta., $13,465-474$.

Bygdeman M., Kwon S. U., Mukherjee T., Wrovist N., Ig68. Effect of intravenous infusion of prostaglandin $\mathrm{E}_{1}$ and $\mathrm{E}_{2}$ on motility of the pregnant humanuterus. Am.J. Obstet. Gynec., 102, 317-326.

Bygdeman M., Toppozada M., Wigvist N., I973. Prostaglandins for induction of abortion and labour. In Prostaglandines 1973, Seminaire, 279-295, I. N. S. E. R. M., Paris.

Challis J. R. G., I974. Physiology and pharmacology of PGs in parturition. Population Rept. Series G., 45-53. Population Information Program, Washington D. C.

Classen M., Koch H., Deyhle P., Weidenhiller S., Demling L., I97o. Wirkung von Prostaglandin $\mathrm{E}_{\mathbf{1}}$ auf die basale Magensekretion des Menschen Klin. Wochenschr., 48, 876-878.

Corey E. J., I97I. Studies of the total synthesis of prostaglandins. Ann. N. Y. Acad. Sci., 180, $24-37$.

Cummings J. H., Newman A., Misiewicz J. J., Milton-Thompson G J., Billings J. A., 1973. Effects of intravenous prostaglandin $F_{2 \alpha}$ on small intestine function in man. Nature (Lond.), 243, I69-I 7 I. 
Cuthbert M. F., I969. Effect on airways resistance of prostaglandin $\mathrm{E}_{1}$ given by aerosol to healthy and asthmatic volunteers. Br. med. $J$., iv, 723-726.

CUthbert M. F., I97I. Bronchodilator activity of aerosols of prostaglandius $\mathrm{E}_{1}$ and $\mathrm{E}_{2}$ in asthmatic subjects. Proc. Roy. Soc. Med., 64, I5-I6.

Csapo A. I., I974. "Prostaglandin impact " for menstrual induction. Population Rept., Series G., 33-40. Population Information Program. Washington, D. C.

Dawson W., Lewis R. L., McMahon R. E., Sweatman W. J. F., I974. Potent bronchoconstrictor activity of $\mathrm{I} 5$-keto prostaglandin $\mathrm{F}_{2 \alpha}$. Nature (Lond.), 250, 33I-332.

Dorp D. A. van, Beerthuis R. K., Nugterex D. H., Vonkeman H., I964. The biosynthesis of prostaglandins. Biochem. Biophys. Acta., 90, 204-207.

Dukes M., Russell W., Walpole A. L., 1974. Potent luteolytic agents related to prostaglandin $F_{2 \alpha}$. Natuve (Lond.), 250, 330-33I.

Embrey M. P., r969. Effect of prostaglandins on the human pregnant uterus. J. Obstet. Gynaec. Br. Cmwlth., $\mathbf{7 6}, 783-789$.

Embrey M. P., r970. Induction of labour with prostaglandins $\mathrm{E}_{1}$ and $\mathrm{E}_{2}$. $\quad$ Br. med. J., ii, 256-258.

Euler U.S. von, I934. Zur Kentnis der pharmakologischen Wirkungen von Nativsekreten und Extrakten männlicher accessorischer Geschlectsdrusen. Arch. exp. Path. Pharmakol., 175, 78-84.

Euler U.S. von, I935. Über die specifische blutdrucksenkende Substanz des menschlichen Prostata und Samenblasensekretes. Klin. Wochenschr., 14, I $182-1183$.

liried J., Santhanakrishnan T.S., Himizu J., Lin C. H., Ford S. H., Rubin B., Grigas E. O., I969. Prostaglandin antagonists: synthesis and smooth muscle activity. Nature (Lond.), 223, $208-210$.

Greenough W. B., Pierce N. F., Al Awqati Q., Carpenter C. C. J., Ig69. Stimulation of gut electrolyte secretion by prostaglandins, theophylline and cholera exotoxin. J. clin. Invest., 48, $32 a$.

Goldblati M. W., I933. A depressor substance in seminal fluid. Chem. Ind. (Lond.), 52, 1056-1057.

Goldblatt M. W., I935. Properties of seminal plasma. J. Physiol. (Lond.), 84, 208-218.

Hamberg M., Samuelsson B., I966. Prostaglandins in humatl seminal plasma. J. biol. Chem., 241, $257-263$.

Hinman J. W., I97o. Prostaglandins: a report on early clinical studies. Postgrad. med. J., 46, 562-575.

Horton E. W., Jonles R. L., x 969 . Prostaglandins $A_{1}, A_{2}$ and I9-hydroxy $A_{1}$ : their actions on smooth muscle and their inactivation on passage through the pulmonary and hepatic portal vascular beds. Br. J. Pharmacol., 37, 705-720.

Jöchle W., Tomlinson R. V., Andersen A. C., I973. Prostaglandin effects on plasma progesterone levels in the pregnant and cycling dog (beagle). Prostaglandins, 3, 209-2I7.

Karim S. M. M., Devlin J., I967. Prostaglandin content of amniotic fluid during pregnancy and labour. J. Obstet. Gynaec. Br. Cmwlth., 74, 230-234.

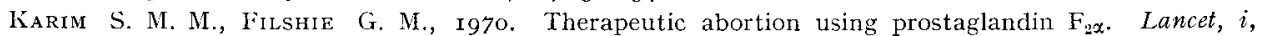
I57-I 59 .

Karim S. M. M., Sandler M., Williams E, D., 1967 . Distribution of prostaglandins in human tissues. Br.J. Pharmacol., 31,340-344.

Karim S. M. M., Hillier K., Devlin J., Ig68a. Distribution of prostaglandins $E_{1}, \mathrm{E}_{2}, \mathrm{~F}_{1 \alpha}$ and $\mathrm{F}_{2 \alpha}$ in some animal tissues. J. Pharmacol., 20, 749-753.

Karim S. M. M., Trussell R. R., PAtel R. C., Hillier K., I968b. Response of pregnant human uterus to prostaglandin $\mathrm{F}_{2 \alpha}$-induction of labour. Br. med. J., iv, 621-623.

Kuert F. A. Jr., I973. Prostaglandins, cyclic nucleotides and cell functions. In Prostaglandines 1973, Seminaire, 55-80, I. N. S. E. R. M., Paris.

Kuenl F. A. Jr., Humes J. L., I972. Direct evidence for a prostaglandin receptor and its application to prostaglandin measurements. Proc. Nat. Acad. Sci., 69, 480-484.

Kurzrok R., Lieb C. C., r93o. Biochemical studies of human semen. II. The action of semen on the human uterus. Proc. Soc. exp. Biol. Med., 28, 268-293.

Nugteren D. H., Dorp D. A. van, Bergström S., Hamberg M., Samuelsson B., ig66. Absolute configuration of the prostaglandins. Nature (Lond,), 212, 38-39.

Pharriss B. B., Wyngarden L. J., I 969 . The effect of prostaglandin $F_{2 \alpha}$ on the progestogen content of ovaries from pseudopregnant rats. Proc. Soc. exp. Biol. Med., 130, 92-94.

Pharriss B. B., Tillson S. A., Erickson R. R., i972. Prostaglandins in luteal function. Rec. Prog. Horm. Res., 28, 5 I-89.

Pharriss B. B., Shaw J. E., I974. Prostaglandins in reproduction. Ann. Rev. Biochem., 36, 39 I-4I 2.

PIKE J. E., I97o. Total synthesis of prostaglandins. Fortschr. Chem. org. Natstoffe., 28, 3I3-342.

Pike J. E., I973. Recent advances in the chemistry of prostaglandins. In Prostaglandines 1973, Seminaire Io3-III, I. S. E. R. M., Paris.

Pike J. E., Kupiecki F. P., Weeks J. R., I967. Biological activity of the prostaglandins and related analogs. In Nobel Symposium 2, Prostaglandins, I61, Almqvist and Wiksell, Stockholm.

Powell W. S., Hammerström S., Samuelsson R., SjöberG B., I974. Prostaglandin $\mathrm{I}_{2 \alpha}$ receptor in human corpora Iutea. Lancet, $i$, II 20. 
Roth-Brandel U., Brgdeman M., Wrovist N., Bergström S., I97o. Prostaglandins for induction of therapeutic abortion. Lancet, $i, \mathrm{I} 90-\mathrm{I} 9 \mathrm{I}$.

Samuelsson B., I973. Biosynthesis and metabolism of prostaglandins. In Prostaglandines 1973, Seminaire, $2 \mathrm{I}-40$, I. N. S. E. R. M., Paris.

Scaramuzzi R. J., Baird D. T., Wheeler A. G., Land R. B., I973. The oestrous cycle of the ewe following active immunization against prostaglandin $F_{2 \alpha}$. Acta endocr. (Copenh.), Suppl. I77, 318.

Shears P., r 968 . The effects of prostaglandin $\mathrm{E}_{\mathbf{1}}$ on isolated bronchial muscle from man. J. Pharm. Pharmacol., 20, 232-233.

Speidel J. J., Ravenholt R. T., i97o. Ideal means of fertility control ? Lancet, $i i, 565$.

Speroff L., Ramwell P. W., r97o. Prostaglandins in reproductive physiology. Am.J.Obstet. Gynec. 107, I I I I-IIZO.

Steinberg D., Vaughan M., Nestel P., Bergström S., i963. Effects of prostaglandin E opposing those of catecholamines on blood pressure and triglyceride breakdown in adipose tissue. Biochem. Pharmac., 12, 764-761.

Stoval R., Jackson R. T., I967. Prostaglandins and nasal blood flow. Ann. Otol. Rhinol. Laryngol., 76, I05I-I059.

Sweatman W. J. F., Collier H. O. J., I968. Effects of prostaglandins on human bronchial muscle. Nature (Lond.), 21\%, 69.

TAYLOR P. L., KELLY R. W., I974. I9-Hydroxylated E prostaglandins as the major prostaglandins in human semen. Nature (Lond.), 250, 665-667.

VAne J. R., 1969. The release and fate of vasoactive hormones in the circulation. Br. J. Pharmac., 35, $209-242$.

VANE J. R., I97I. Inhibition of prostaglandin synthesis as a mechanism of action for aspirin-like drugs. Nature New Biol., 231, 232-235.

WALlach D. P., I965. The enzymic conversion of arachidonic acid to prostaglandin $E_{2}$ with acetone powder preparations of bovine seminal vesicles. Life Sci., 4, 36r-364.

Wilson D. E., Phillips C., Levine R. A., I97o. Inhibition of gastric secretion in man by prostaglandin $\mathrm{A}_{1}$. Gastroenterology, 58, 1007 a. 